\title{
IMMUNITY TO RHODOCOCUS EQUI INFECTION IN HORSES
}

\author{
Ljiljana Suvajdžićc ${ }^{*}$, Aleksandar Potkonjak², Dubravka Milanov ${ }^{3}$, \\ Maja Bekut ${ }^{4}$, Anika Trudić ${ }^{5}$, Milenko Lazić ${ }^{6}$, Zoran Suvajdžić ${ }^{7}$ \\ ${ }^{1}$ Department of Pharmacy, Faculty of Medicine, \\ University of Novi Sad, Novi Sad, Serbia \\ ${ }^{2}$ Department of Veterinary Medicine, Faculty of Agriculture, \\ University of Novi Sad, Novi Sad, Serbia \\ ${ }^{3}$ Scientific Veterinary Institute "Novi Sad", Novi Sad, Serbia \\ ${ }^{4}$ Faculty of Medicine, University of Novi Sad, Novi Sad, Serbia \\ ${ }^{5}$ Center for Microbiology, Institute for Pulmonary Diseases \\ of Vojvodina, Sremska Kamenica, Serbia \\ ${ }^{6}$ Hemofarm Stada, Vršac \\ ${ }^{7}$ Veterinary practice STRIKS, Čerević, Serbia
}

\section{Abstract}

Rhodococcus equi is an opportunistic bacterium that commonly infects foals and immunocompromised patients. Due to the large economic losses that it can cause in the field of horse breeding, the microorganism has been studied in details, including its immunological aspect. Within the humoral immunity, the most important immunoglobulins are those of the class $G$ (IgG), produced as a response to the surface antigen associated with virulence (virulence associated protein A, VapA). IgG antibodies provide resistance to pneumonia in foals and have a dose dependent protective effect. In addition to them, the protective role of plasma is achieved through various cytokines. Cellular mechanisms are important for killing bacteria within the macrophage. Virulent strains which carry a plasmid with the gene for VapA stimulate the production of interferon gamma (IFN- $\gamma$ ), a key cytokine to kill these bacteria. The presence of IFN- $\gamma$ is crucial for the removal of microorganisms from the lungs and prevention of formation of pulmonary granulomas. For the complete removal of bacteria cooperation of the humoral and cellular immunity is necessary. Particularly significant is opsonization, which increases phagolysosomal fusion. Vaccination and

\footnotetext{
${ }^{1^{*}}$ corresponding author: Ljiljana Suvajdžić; email adress: giba57@eunet.rs
} 
application of hyperimmune plasma play a vital role in the treatment of disease. Only alive and virulent bacterium is capable of producing protective immunity in horses. The use of hyperimmune plasma in foals results in a lower percentage of sick animals and less severe clinical progression of the disease. Further research is needed in order to create a safe and effective vaccine.

Key words: Rhodococcus equi, immunity, horses, vaccine

\title{
IMUNITET KOD KONJA NA RHODOCOCCUS EQUI INFEKCIJU
}

\author{
Ljiljana Suvajdžićc ${ }^{1 *}$, Aleksandar Potkonjak², Dubravka Milanov³, \\ Maja Bekut ${ }^{4}$, Anika Trudićs ${ }^{5}$ Milenko Lazić ${ }^{6}, Z_{\text {Zoran Suvajdžić }}^{7}$ \\ ${ }^{1}$ Departman za farmaciju, Medicinski fakultet, \\ Univerzitet u Novom Sadu, Novi Sad, Srbija \\ ${ }^{2}$ Department za veterinarsku medicinu, Poljoprivredni \\ fakultet, Univerzitet u Novom Sadu, Novi Sad, Srbija \\ ${ }^{3}$ Naučni institut za veterinarstvo "Novi Sad", Novi Sad, Srbija \\ ${ }^{4}$ Medicinski fakultet, Univerzitet u Novom Sadu, Novi Sad, Srbija \\ ${ }^{5}$ Centar za mikrobiologiju, Institut za plućne bolesti \\ Vojvodine, Sremska Kamenica, Srbija \\ ${ }^{6}$ Hemofarm Stada, Vršac \\ ${ }^{7}$ Veterinarska ambulanta STRIKS, Čerević, Srbija
}

\section{Kratki sadržaj}

Rhodococcus equi je uslovno patogena bakterija koja najčešće inficira ždrebad i imunokompromitovane pacijente. Zbog velikih ekonomskih gubitaka koje može da izazove u uzgoju konja, mikroorganizam je detaljno proučen, između ostalog sa imunološkog aspekta. U okviru humoralnog imuniteta, najznačajniji su imunoglobulini klase G (IgG), nastali na površinski antigen udružen sa virulencijom (virulence associated protein $A$, VapA). IgG povećavaju otpornost ždrebadi na pneumonije, a imaju dozno zavisno zaštitno delovanje. Pored antitela, zaštitna uloga plazme ostvaruje se preko različitih citokina. Celularni mehanizmi ubijanja su značajni zbog ubijanja bakterije unutar makrofaga. Virulentni sojevi koji su nosioci plazmida sa genom za VapA stimulišu produkciju gama interferona (IFN- $\gamma$ ), 
ključnog citokina za ubijanje bakterija. Prisustvo IFN- $\gamma$ je presudno za uklanjanje mikroorganizma iz pluća i sprečavanje nastanka plućnih granuloma. Za potpuno odstranjenje bakterija, neophodna je kooperacija humoralnog i celularnog imuniteta. Posebno je značajna opsonizacija, koja povećava fagolizozomalnu fuziju. Vakcinacija i primena hiperimune plazme zauzimaju značajno mesto u terapiji bolesti. Samo živa i virulentna bakterija je sposobna da izazove zaštitan imunitet kod konja. Primena hiperimune plazme kod ždrebadi rezultuje manjim procentom obolelih jedinki i manje ozbiljnim kliničkim tokom bolesti. Neophodna su dalja istraživanja u cilju kreiranja bezbedne i efikasne vakcine.

Ključne reči: Rhodococcus equi, imunitet, konji, vakcine

\section{INTRODUCTION}

Rhodococcus equi ( $R$. equi) is an intracellular bacterium that survives mechanisms of phagolysosomal fusion, which compromises the effectiveness of antibiotic therapy (von Bargen and Haas, 2009). The microorganism is present in the soil, on all continents except Antarctica (Prescott, 1991).

It causes diseases in various animal species (Takai et al., 1996; Suvajdžić, 2000; Suvajdžić et al., 2001; Flynn et al., 2001; Takai et al., 2003; von Bargen and Haas, 2009) but predominantly in horses (Prescott, 1991; Muscatello, 2012a; Suvajdžić et al., 2015), which is why this bacterium is called "equinocentric" (Vázquez-Boland et al., 2013).

It can be found in the soil of 50-95\% households which breed horses, as R. equi is present in horses' feces in very high concentrations. In the feces of mares, $R$. equi is present in concentration from $10^{2}$ to $10^{3}$ colony forming units (CFU) per gram. It is isolated from the feces of foals, starting from the first week of life. In the feces of four weeks old foals it is present in the amount from $10^{4}$ to $10^{5} \mathrm{CFU}$. Such high concentration stays up to 8 and 10 weeks of age, when it starts to decrease and, as foals are maturing, settles to the concentration characteristic for mares (Takai, 1997). This is in accordance with the research of optimal doses for the foal experimental challenge. The dose of $10^{2} \mathrm{CFU}$ gave mild clinical presentation, mimicking natural infection (Sanz et al., 2013). The highest excretion by feces, $10^{6}$ to $10^{8} \mathrm{CFU}$ per gram, appears in the period until 8 weeks of life, precisely at the time when the foals are most receptive to infections (Takai, 1997).

In human population, infections by $R$. equi often affect immunocompromised patients (Weinstock and Brown, 2002; Suvajdžić and Považan, 2006; Tuon et al., 2007). Ten percent of infected patients were already being treated with 
immunosuppressive drugs, which are an integral part of the therapy during organ transplantation and in autoimmune diseases (La Rocca et al., 1998). It is believed that about two-thirds of patients infected with $R$. equi suffer from HIV (Harvey and Sunstrum, 1991). However, it can also cause diseases in immunocompetent persons (Kedlaya et al., 2001; Suvajdžić, 2004; Suvajdžić et al., 2015).

Managing control and prevention of this disease in veterinary medicine represents an economic category for the single reason that losses which may occur in the case of an epidemic in stables, especially of thoroughbred horses, would be enormous. In addition to general hygiene and sanitation, specific active and passive prophylaxis should occupy the place they deserve in the system of overseeing animal health (Muscatello, 2012a).

\section{IMMUNITY IN RHODOCOCCUS EQUI INFECTIONS}

Rhodococcus equi usually infects foals and very rarely adult horses (Vázquez-Boland et al., 2013). Infections occur sporadically, except in foals, where they can have enzootic character. The immune system has a key role in development of infection. In foals, the infection is associated with the period of vanishing of maternal antibodies present in colostrum. In adult animals, accommodation, food and environmental conditions have a significant role in the course of infection, mainly due to their effect on the general immunological conditions (Muscatello, 2012b).

Infection of foals occurs within the first week of life. The onset of clinical signs occurs approximately in 50 days. This also indicates that the incubation period is longer in natural infections, when compared to extremely high inocula sizes used in experiments. (Horowitz et al., 2001).

There are implications that some mares give birth to foals that are particularly sensitive to $R$. equi infections. Such sensitivity can be explained by low levels of colostrum antibodies, functional immaturity of neutrophils in some foals, or genetic predisposition to infections (Wilks et al., 1982).

Due to the big impact on the health of horses, studies of immune response to infection with R. equi were mostly conducted on horses, in addition to murine models. Many aspects of immunological reactivity of horses were investigated, including both cellular and humoral mechanisms.

\section{HUMORAL IMMUNITY IN HORSES}

The digestive tract is probably the main source of antigenic stimulation of $R$. equi in horses. In foals, the level of maternal antibodies decline to the 
lowest level in the period of eight weeks of age, after which foals are actively producing antibodies. Foals with low levels of colostral antibodies, detected by an ELISA test, are particularly vulnerable to rhodococcal pneumonia (Hietala and Ardans, 1987). Those with higher levels of antibodies show a milder form of the disease (Martens et al., 1989). Accordingly, the maximum sensitivity of foals occurs in the period between 2 and 6 months of age (Hines et al., 1997).

The protective role of antibodies that are produced as the response to the surface antigen virulence-associated protein A (VapA) was shown. The G class of immunoglobulins ( $\operatorname{IgG})$, created against this antigen was present in bigger concentration when compared to the concentration obtained by immunization with intact but killed R. equi. Also, the increase in the mare serum opsonizing activity is more pronounced in the group that received the VapA antigen compared to the group that received the whole bacteria (Cauchard et al., 2004).

Immunoglobulins created to VapA can be considered a diagnostic parameter in horses' infection, (Sanz et al., 2016), bearing in mind that this antigen is unique to equin $R$. equi - human or other animal's isolated strains did not posses this antigen (Occampo- Sosa et al., 2007)

In the study of IgG to VapA and IgG subclasses, it is shown that VapA- specific $\operatorname{IgG}(\mathrm{T})$ is the first antibody with the increase of titar. Also, this immunoglobulin is potentially revised as a prognostic parameter in detection of naturally occurring rhodococcal pneumonia (Sanz et al., 2015).

After infection, subclasses of detected antibodies include IgGa, IgGb, IgGc and IgM, with significantly higher levels of IgGa and IgGb subclasses in foals than in horses. (Jacks et al., 2007a) Isotype IgGa is the most important in the prevention of pneumonia in foals (Hooper-McGrevy et al., 2003).

Antibodies against the VapA antigen administered to mice showed a dose-dependent protective effect. After exposure to $R$. equi, the control group without applied antibodies died. The group that received a lower dose of the antibodies was partially protected, although the pathohistological examination showed bacteria in the spleen or lungs. In the mice that received the full dose, there were no deaths or signs of the disease, nor was the microorganism found in their tissues (Fernandez et al., 1997).

However, in a study that examined the passive immunization, in a colt with very low titer of antibodies, there have been no clinical manifestations of the disease, while another colt with a high titer developed serious illness with infausto prognosis. Levels of antibodies are not always in correlation with the opsonizing activity. Therefore, it is assumed that non-specific plasma factors, such as lymphokines and interferons, can also impact the protective effect of the immune plasma (Martens et al., 1989). 


\section{CELLULAR IMMUNITY IN HORSES}

Bearing in mind the intracellular nature of $R$. equi, it is believed that cellmediated mechanisms are the most effective against this disease (Vázquez-Boland et al., 2013). Aside from the disappearance of maternal antibodies, the decreased killing capacity of macrophages in foals contributes to their susceptibility in age of 1-5 months. (Berghaus et al., 2014)

The study which compared bronchoalveolar and monocyte- derived macrophages, revealed that the replication of $R$. equi is greater in bronchoalveolar macrophages, with 3- 100 fold increase during 48 hours (Berghaus et al., 2014). This is logical, having in mind that predominant route of infection is aerosol inhalation of R. equi (Giguère et al., 2011a).

Rhodococcus is able to survive intracellularly and to replicate in macrophages, both in murine peritoneal, as well as equine alveolar. The number of bacteria increases with time after the initial phase lag period of the first 6-12 hours of infection, during which the number of intracellular bacteria remains unchanged. During the subsequent 36 hours, the number increases five fold or more, to the inability of quantification, while preserving cell viability. A similar phenomenon was observed with mycobacteria, with the fact that $R$. equi more rapidly divides. Replication within macrophages is characteristic of $R$. equi strains that possess VapA (Hondalus and Mosser, 1994).

The first step in intracellular killing of pathogens is macrophage activation by interferon gamma. The $\mathrm{CD} 4+$ and $\mathrm{CD} 8+\mathrm{T}$ lymphocytes from the lungs are able to produce interferon gamma (INF- $\gamma$ ) (Hines et al., 2003). Pulmonary clearance of the pathogen depends precisely of the increase in the number of pulmonary T cells and IFN- $\gamma$ production (Kanaly et al., 1995; Hines et al., 2001; Hines et al., 2003).

In studies conducted on mice, it has been shown that there are two phenotypes of CD4+ T lymphocytes, which are referred to as Th1 and Th2. The classification was based on the cytokines they produce: IFN- $\gamma$ is characteristic of the Th1 phenotype, IL- 4 of the Th2. The transfer of adequate cell lines, demonstrated that Th1 phenotype led to the complete removal from the lungs (zero CFU), while in the Th2 lines led to the development of pulmonary granuloma. Natural killer (NK) cells can also produce INF- $\gamma$, but transferring them alone does not lead to clearance of bacteria from the lungs (Kanaly et al., 1996). The production of IFN- $\gamma$ in horses is triggered by VapA. It causes the same later response in horses as well as in mice (Hines et al., 2001; Lopez et al., 2002). Since the protein VapA is encoded by the vapA gene located on the plasmid (Tan et al., 1995), only the virulent strains, carriers of this plasmid, may be removed from the lungs (Hines et al., 2003). 
Infection of macrophages by $R$. equi leads to a rapid translocation of NF$\kappa \mathrm{B}$ (nuclear factor kappa-light-chain-enhancer of activated B cells) from cytoplasm into nucleus, resulting in production of large amounts of inflammatory cytokines. Some of the most important are TNF, interleukin IL-12 and nitric oxide, NO. There is an assumption that these paths of non specific immunity are the main reason why the microorganism rarely causes diseases in immunocompetent adult animals (Darrah et al., 2004).

In a study on normal human peripheral blood mononuclear cells it has been demonstrated that they secrete TNF- $\alpha$, IL- 6 and IL- 8 when they are stimulated with killed $R$. equi. Levels of TNF- $\alpha$ were increasing during the first 48 hours, wherein the $90 \%$ of secreted cytokines were detected after 36 hours. For IL-6, this level was reached after only 12 hours. Production of IL- 8 was at its maximum at the beginning, and leveled off between 12 and 48 hours (Pece et al., 1997).

The effect of foal's age on cytokine production is also revised. The expression of production signals in bronchoalveolar macrophages for IL- $1 \beta$, IL-10, IL12 p40 and IL-8, as well as IL- $1 \beta$ and IL-12 p40 production signals in bronchoalveolar lavage macrophages in 1-3 days old foals is higher than in foals of other age. This also indicates exposure to infection with $R$. equi in very early period of life (Berghaus et al., 2014).

It has been shown that the lack of galectin-3 receptor increases resistance to R. equi infections. Mice with and without this receptor were compared. Macrophages lacking this receptor are less susceptible to $R$. equi, its reproduction and survival. This receptor normally provides a balanced response to nonspecific immunity, affecting the production of IL- $1 \beta$ by macrophages (Ferraz et al., 2008).

\section{COOPERATION OF HUMORAL AND CELLULAR IMMUNITY}

The best descriptions of important interactions between cell-mediated immunity and humoral immunity come from in vitro studies that have investigated the mechanisms of killing R. equi by macrophages (Hietala and Ardans, 1987).

Alveolar macrophages in foals experimentally exposed to $R$. equi phagocyte and kill both non opsonized and opsonized microorganisms more efficiently than alveolar macrophages in foals that were not exposed to the bacteria. Macrophage activity in foals which were already in contact with $R$. equi, was similar to the macrophage activity in adult horses. However, the rate of killing of opsonized $R$. equi was slightly lower in foals than in horses. In 
all tested alveolar macrophages, opsonization of $R$. equi significantly increases phagolysosomal fusion when compared to nonopsonized bacteria (Hietala and Ardans, 1987; Giguère et al., 2011).

The use of plasma with antibodies also decreased bacterial viability in the extracellular matrix, but not in the macrophages (Dawson et al., 2011).

\section{IMMUNOPROPHYLAXIS AND IMMUNOTHERAPY IN HORSES}

Conventional therapy with antibiotics, with some being more effective than others (Giguère et al., 2015), is practically impossible without immunological support, with nature taking its course (Berghaus et al., 2011). Scientific attempts, with various approaches to increasing antibiotics in target sites included streptolysin O (Horohov et al., 2011; Gurel et al., 2013) and liposomal forms of antibiotic (Burton et al., 2015). In this way, we can "help nature" with immunomodulating support.

Field research conducted by Magnusson in 1923 and 1924 failed to justify vaccination with an inactivated culture of $R$. equi. Vaccination of foals with isolates of $R$. equi, which were inactivated with formalin, failed to protect animals from a strong intratracheal exposure to the bacteria (Magnusson, 1923).

Lopez et al. (2008) tested a live attenuated strain of $R$. equi which was a riboflavin auxotroph on a mouse and a colt. This strain has kept the virulence plasmid. However, in a vaccine it is important to balance immunogenicity and attenuation. It is shown that such a vaccine must increase immunogenicity to demonstrate its success in neonatal foals. In order to make disease prevention more effective on endemic farms, a vaccine should be able to induce an immune response very early in life (Lopez et al., 2008). Currently, there is no vaccine, but new candidates are being tested (Cauchard et al., 2013).

Other attempts with immunostimulans containing Propionibacterium acnes showed no effect as imunomodulators in therapy in foals (Sturgill et al., 2011).

Pneumonia in foals can be prevented by vaccination of pregnant mares. These vaccines contained VapA and exoenzim. The result of this research was the decline of mortality rates in cases of rhodococcal pneumonia on farms that have vaccinated mares from 3\% to 1.2\% (Becú et al., 1997).

Studies on a few endemic farms in Japan, United States and Argentina have shown that administration of hyperimmune plasma in foals led to protection in the earliest period of life. Some of the recommendations for prevention of pneumonia are: separation of foals in clean and ventilated paddocks, serological testing on 30th and 45th days after birth and immunization with plasma 
immediately after birth (Higuchi et al., 1999), no later than second day of life (Giguère et al., 2011a; Vázquez-Boland et al., 2013)

Unspecific measures, such as feces removal from paddocks, avoiding spreading manure on pastures, irrigation of holding pens, foaling at pastures- gave unsatisfying results (Giguère et al., 2011b)

\section{CONCLUSION}

Only alive and virulent $R$. equi bacteria can cause immunity in mice. Avirulent live strains and the strains that were killed by heat did not show this activity (Takai et al., 1999). Effective immunization against intracellular bacterial pathogens requires the use of living microorganisms, rather than inactivated, in order to initiate a cellular immune response (Collins, 1988).

In passive immunization, the quality of donor's plasma is crucial: immunized donor's plasma protects significantly from severe illnesses when compared to non immunized donor's plasma (Martens et al., 1989). In vitro reaction of passively immunized foals was similar to actively immunized mares (Becú et al., 1997).

In our country there is no immunoprophylaxis or immunotherapy for $R$. equi. Would it be reasonable to take into consideration collecting indigenous isolates, determining antigens and creating a vaccine that covers the antigenic determinants (including VapA) present in our area? Serum production on the same isolates could be professionally, scientifically and economically justified.

\section{AKNOWLEDGMENTS}

This work has been financially supported by a grant from Ministry of Education, Science and Technological Development, Republic of Serbia, Project numbers III 46012 and III 41012.

The authors wish to thank Milica Radovanović for her revision of the English language.

\section{REFERENCES}

1. Becú T., Polledo G., Gaskin JM.: Immunoprophylaxis of Rhodococcus equi pneumonia in foals. Veterinary Microbiology, 56, 3-4, 193-204, 1997

2. Berghaus LJ., Giguère S., Sturgill TL.: Effects of age and macrophage lineage on intracellular survival and cytokine induction after infection with Rhodococcus equi. Veterinary Immunology and Immunopathology, 160, 1-2, 41-50, 2014 
3. Burton AJ., Giguère S., Berghaus LJ., Hondalus MK., Arnold RD.: Efficacy of liposomal gentamicin against Rhodococcus equi in a mouse infection model and colocalization with $R$. equi in equine alveolar macrophages. Veterinary Microbiology, 176, 3-4, 292-300, 2015

4. Cauchard J., Sevin C., Ballet JJ., Taouji S.: Foal IgG and opsonizing antiRhodococcus equi antibodies after immunization of pregnant mares with aprotective VapA candidate vaccine. Veterinary Microbiology, 104, 1-2, 73 81,2004

5. Cauchard S., Giguère S., Venner M., Muscatello G., Cauchard J., Cohen ND., Haas A., Hines SA., Hondalus MK., Horohov DW., Meijer WG., Prescott JF., Vázquez-Boland J.: Rhodococcus equi research 2008-2012: report of the Fifth International Havemeyer Workshop. Equine Veterinary Journal, $45,5,523-526,2013$

6. Collins FM.: AIDS-related mycobacterial disease. Springer Seminars in Immunopathology, 10, 4, 375-391, 1988

7. Darrah PA., Monaco MC., Jain S., Hondalus MK., Golenbock DT., Mosser DM.: Innate immune responses to Rhodococcus equi. The Journal of Immunology, 173, 3, 1914-1924, 2004

8. Dawson DR., Nydam DV., Price CT., Graham JE., Cynamon MH., Divers TJ., Felippe MJ.: Effects of opsonization of Rhodococcus equi on bacterial viability and phagocyte activation. American Journal of Veterinary Research, 72, 11, 1465-1475, 2011

9. Dawson TR., Horohov DW., Meijer WG., Muscatello G.: Current understanding of the equine immune response to Rhodococcus equi. An immunological review of $R$. equi pneumonia. Veterinary Immunology and Immunopathology, 135, 1-2, 1-11, 2010

10. Fernandez AS., Prescott JF., Nicholson VM.: Protective effect against Rhodococcus equi infection in mice of IgG purified from horses vaccinated with virulence associated protein (VapA)-enriched antigens. Veterinary Microbiology, 56, 3-4, 187-192, 1997

11. Ferraz LC., Bernardes ES., Oliveira AF., Ruas LP., Fermino ML., Soares SG., Loyola AM., Oliver C., Jamur MC., Hsu DK., Liu FT., Chammas R., Roque-Barreira MC.: Lack of galectin-3 alters the balance of innate immune cytokines and confers resistance to Rhodococcus equi infection. European Journal of Immunology, 38, 10, 2762-2775, 2008

12. Flynn O., Quigley F., Costello E., O’Grady D., Gogarty A., Mc Guirk J., Takai S.: Virulence-associated protein characterisation of Rhodococcus equi isolated from bovine lymph nodes. Veterinary microbiology, 78, 3, 221228,2001 
13. Giguère S., Berghaus LJ., Lee EA.: Activity of 10 antimicrobial agents against intracellular Rhodococcus equi. Veterinary Microbiology, 178, 3-4, 275278,2015

14. Giguère S., Cohen ND., Chaffin MK., Hines SA., Hondalus MK., Prescott JF., Slovis NM.: Rhodococcus equi: clinical manifestations, virulence, and immunity. Journal of Veterinary Internal Medicine, 25, 6, 1221-1230, 2011

15. Giguère S., Cohen ND., Chaffin MK., Slovis NM., Hondalus MK., Hines SA., Prescott JF.: Diagnosis, treatment, control, and prevention of infections caused by Rhodococcus equi in foals. Journal of Veterinary Internal Medicine, 25, 6, 1209-1220, 2011

16. Gurel V., Lambert K., Page AE., Loynachan AT., Huges K., Timoney JF., Fettinger M., Horohov DW., McMichael J.: Streptolysin-O/antibiotics adjunct therapy modulates site-specific expression of extracellular matrix and inflammatory genes in lungs of Rhodococcus equi infected foals. Veterinary Research Communications, 37, 2, 145-154, 2013

17. Harvey RL., Sunstrum JC.: Rhodococcus equi infection in patients with and without human immunodeficiency virus infection. Reviews of Infectious Diseases, 13, 1, 139-145, 1991

18. Hietala SK., Ardans AA.: Interaction of Rhodococcus equi with phagocytic cells from $R$. equi-exposed and non-exposed foals. Veterinary Microbio$\log y, 14,3,307-320,1987$

19. Higuchi T., Arakawa T., Hashikura S., Inui T., Senba H., Takai S.: Effect of prophylactic administration of hyperimmune plasma to prevent Rhodococcus equi infection on foals from endemically affected farms. Journal of Veterinary Medicine, 46, 9, 641-648, 1999

20. Hines MT., Paasch KM., Alperin DC., Palmer GH., Westhoff NC., Hines SA.: Immunity to Rhodococcus equi: antigen-specific recall responses in the lungs of adult horses. Veterinary Immunology and Immunopathology, $79,1-2,101-114,2001$

21. Hines SA., Kanaly ST., Byrne BA., Palmer GH.: Immunity to Rhodococcus equi. Veterinary Microbiology, 56, 3-4, 177-185, 1997

22. Hines SA., Stone DM., Hines MT., Alperin DC., Knowles DP., Norton LK., Hamilton MJ., Davis WC., McGuire TC.: Clearance of virulent but not avirulent Rhodococcus equi from the lungs of adult horses is associated with intracytoplasmic gamma interferon production by CD4+ and CD8+ T lymphocytes. Clinical and Diagnostic Laboratory Immunology, 10, 2, 208215,2003

23. Hondalus MK., Mosser DM.: Survival and replication of Rhodococcus equi in macrophages. Infection and Immunity, 62, 10, 4167-4175, 1994 
24. Hooper-McGrevy KE., Wilkie BN., Prescott JF.: Immunoglobulin G subisotype responses of pneumonic and healthy, exposed foals and adult horses to Rhodococcus equi virulence-associated proteins. Clinical and Diagnostic Laboratory Immunology, 10, 3, 345-351, 2003

25. Horohov DW., Loynachan AT., Page AE., Hughes K., Timoney JF., Fettinger M., Hatch T., Spaulding JG., McMichael J.: The use of streptolysin O (SLO) as an adjunct therapy for Rhodococcus equi pneumonia in foals. Veterinary Microbiology, 154, 1-2, 156-162, 2011

26. Horowitz ML., Cohen ND., Takai S., Becu T., Chaffin MK., Chu KK., Magdesian KG., Martens RJ.: Application of Sartwell's model (lognormal distribution of incubation periods) to age at onset and age at death of foals with Rhodococcus equi pneumonia as evidence of perinatal infection. Journal of Veterinary Internal Medicine, 15, 3, 171-175, 2001

27. Jacks S., Giguère S., Crawford PC., Castleman WL.: Experimental infection of neonatal foals with Rhodococcus equi triggers adult-like gamma interferon induction. Clinical and Vaccine Immunology, 14, 6, 669-677, 2007a

28. Jacks S., Giguère S., Prescott JF.: In vivo expression of and cell-mediated immune responses to the plasmid-encoded virulence-associated proteins of Rhodococcus equi in foals. Clinical and Vaccine Immunology, 14, 4, 369-374, 2007b

29. Kanaly ST., Hines SA., Palmer GH.: Cytokine modulation alters pulmonary clearance of Rhodococcus equi and development of granulomatous pneumonia. Infection and Immunity, 63, 8, 3037-3041, 1995

30. Kanaly ST., Hines SA., Palmer GH.: Transfer of a CD4+ Th1 cell line to nude mice effects clearance of Rhodococcus equi from the lung. Infection and Immunity, 64, 4, 1126-1132, 1996

31. Kedlaya I., Ing MB., Wong SS.: Rhodococcus equi infections in imunnocompetent hosts: case report and review. Clinical Infectious Diseases, 32, 3, E39-46, 2001

32. La Rocca E., Gesu G., Caldara R., Maffi P., Del Maschio A., Vanzulli A., Castoldi R., Di Carlo V., Pozza G., Secchi A.: Pulmonary infection caused by Rhodococcus equi in a kidney and pancreas transplant recipient: a case report. Transplantation, 65, 11, 1524-1525, 1998

33. Lopez AM., Hines MT., Palmer GH., Alperin DC., Hines SA.: Identification of pulmonary T-lymphocyte and serum antibody isotype responses associated with protection against Rhodococcus equi. Clinical and Diagnostic Laboratory Immunology, 9, 6, 1270-1276, 2002

34. Lopez AM., Townsend HG., Allen AL., Hondalus MK.: Safety and immunogenicity of a live-attenuated auxotrophic candidate vaccine against the intracellular pathogen Rhodococcus equi. Vaccine, 26, 7, 998-1009, 2008 
35. Magnusson H.: Spezifische infektiöse pneumonie beim fohlen: ein neuer eitererreger beim pferd. Archiv für Wisseenschaftliche und Praktische Tierheilkunde, 50, 22-38, 1923

36. Martens RJ., Martens JG., Fiske RA., Hietala SK.: Rhodococcus equi foal pneumonia: protective effects of immune plasma in experimentally infected foals. Equine Veterinary Journal, 21, 4, 249-255, 1989

37. Muscatello G.: Rhodococcus equi pneumonia in the foal- part 1: Pathogenesis and epidemiology. The Veterinary Journal, 192, 1, 20-26, 2012b

38. Muscatello G.: Rhodococcus equi pneumonia in the foal- part 2: Diagnostics, treatment and disease management. The Veterinary Journal 192,1, 27-33, 2012a

39. Ocampo-Sosa AA., Lewis DA., Navas J., Quigley F., Callejo R., Scortti M., Leadon DP., Fogarty U., Vazquez-Boland JA.: Molecular epidemiology of Rhodococcus equi based on traA, vapA, and vapB virulence plasmid markers. The Journal of Infectious Diseases, 196, 5, 763-769, 2007

40. Pece S., Giuliani G., Fumarola D., Mastroianni CM., Lichtner M., Vullo V., Antonaci S., Jirillo E.: In vitro production of tumor necrosis factor-alpha, interleukin- 6 and interleukin-8 from normal human peripheralblood mononuclear cells stimulated by Rhodococcus equi. Veterinary Microbiology, 56, 3-4, 277-285, 1997

41. Prescott JF.: Rhodococcus equi: an animal and human pathogen. Clinical Microbiology Reviews, 4, 1, 20-34, 1991

42. Sanz M., Loynachan A., Sun L., Oliveira A., Breheny P., Horohov DW.: The effect of bacterial dose and foal age at challenge on Rhodococcus equi infection. Veterinary Microbiology, 167, 3-4, 623-631, 2013

43. Sanz MG., Oliveira AF., Loynachan A., Page A., Svansson V., Giguère S., Horohov DW.: Validation and evaluation of VapA-specific IgG and IgG subclass enzyme-linked immunosorbent assays (ELISAs) to identify foals with Rhodococcus equi pneumonia. Equine Veterinary Journal, 48, 1, 103108, 2016

44. Sanz MG., Villarino N., Ferreira-Oliveira A., Horohov DW.: VapA-specific IgG and IgG subclasses responses after natural infection and experimental challenge of foals with Rhodococcus equi. Veterinary Immunology and Immunopathology, 164, 1-2, 10-15, 2015

45. Sturgill TL., Strong D., Rashid C., Betancourt A., Horohov DW.: Effect of Propionibacterium acnes-containing immunostimulant on interferongamma (IFN $\gamma)$ production in the neonatal foal. Veterinary Immunology and Immunopathology, 141, 1-2, 124-127, 2011 
46. Suvajdžić Lj., Petej Z., Milanov D., Trailović D.: Rhodocuccus equi izolovan iz pluća ždrebeta - prikaz slučaja. Book of proceedings, Clinica Veterinaria- Third Symposium in Animal Clinical Pathology and Therapy, Jun 1115, 2001, Budva, Montengro, organized by Faculty of veterinary medicine, University of Belgrade, Faculty of veterinary medicine, University of Skopje and Veterinary Association of Montenegro, 323-324

47. Suvajdžić Lj., Považan Đ.: Identification on Rhodococcus equi from pulmonary malakoplakia. Book of proceedings, Infections and lung diseases, Jun 8-9, 2006, Paris, France, organized by Institut Pasteur, Euroconferences, $45 / 15$

48. Suvajdžić Lj., Velhner M., Bekut M., Bojić G., Krstić T., Suvajdžić Z., Lazić M. Comparison of Rhodococcus equi of human and animal origin. Proceedings, One Health- New Challenges: First International Symposium of Veterinary Medicine ISVM2015, May 21-23, 2015, Vrdnik, Serbia, organized by Scientific Veterinary Institute "Novi Sad", Novi Sad, 405-413

49. Suvajdžić Lj.: Izučavanje karakteristika Actinomyces pyogenesa i sličnih mikroorganizama izolovanih iz pluća teladi i prasadi sa pneumonijom [dissertation]. Beograd: Univezitet u Beogradu, 2000

50. Suvajdžić Lj.: Rhodococcus equi. Isolation from the eye of patient- first human isolate in Serbia and Montenegro. Book of proceedings, 3rd Congres of the ESEI Oct 17-20, 2004; Paris, France, organized by ESEI- European Society for Emerging Infections, 111

51. Takai S., Fukunaga N., Ochiai S., Imai Y., Sasaki Y., Tsubaki S., Sekizaki T.: Identification of intermediately virulent Rhodococcus equi isolates from pigs. Journal of Clinical Microbiology, 34, 4, 1034- 1037, 1996

52. Takai S., Kobayashi C., Murakami K., Sasaki Y., Tsubaki S.: Live virulent Rhodococcus equi, rather than killed or avirulent, elicits protective immunity to R. equi infection in mice. FEMS Immunology and Medical Microbiology, 24, 1, 1-9, 1999

53. Takai S., Martens RJ., Julian A., Garcia Ribeiro M., Rodrigues de Farias M., Sasaki Y., Inuzuka K., Kakuda T., Tsubaki S., Prescott JF.: Virulence of Rhodococcus equi isolated from cats and dogs. Journal of Clinical Microbiology, 41, 9, 4468- 4470, 2003

54. Takai S.: Epidemiology of Rhodococcus equi infections: a review. Veterinary Microbiology, 56, 3/4, 167-176, 1997

55. Tan C., Prescott JF., Patterson MC., Nicholson VM.: Molecular characterization of a lipid-modified virulence-associated protein of Rhodococcus equi and its potential in protective immunity. Canadian Journal of Veterinary Research, 59, 1, 51-59, 1995 
56. Tuon FF., Siciliano RF., Al-Musawi T., Rossi F., Capelozzi VL., Gryschek RC., Medeiros EA. Rhodococcus equi bacteremia with lung abscess misdiagnosed as corynebacterium: a report of 2 cases. Clinics (Sao Paulo), 62, 6, 795-798, 2007

57. Vázquez-Boland JA., Giguère S., Hapeshi A., MacArthur I., Anastasi E., Valero-Rello A.: Rhodococcus equi: the many facets of a pathogenic actinomycete. Veterinary Microbiology, 167, 1-2, 9-33, 2013

58. von Bargen K., Haas A.: Molecular and infection biology of the horse pathogen Rhodococcus equi. FEMS Microbiology Reviews, 33, 5, 870-891, 2009

59. Weinstock DM., Brown AE.: Rhodococcus equi: An Emerging Pathogen. Clinical Infectious Diseases, 34, 10, 1379-1385, 2002

60. Wilks CR., Barton MD., Allison JF.: Immunity to and immunotherapy for Rhodococcus equi. Journal of Reproduction and Fertility Supplement, 32, 497-505, 1982

Primljeno: 25.11.2015.

Odobreno: 15.01.2016. 